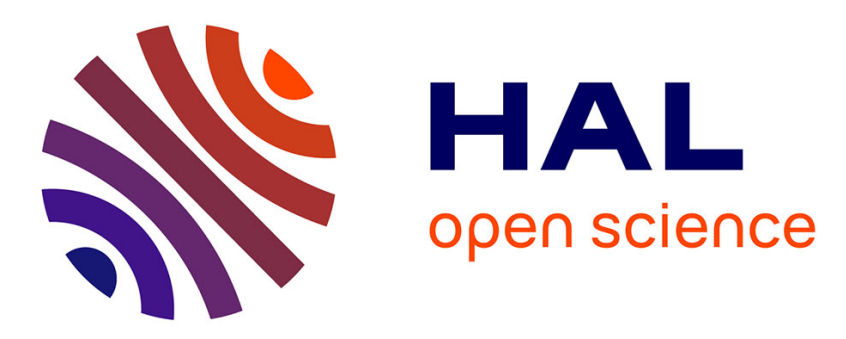

\title{
Key parameters influencing the uptake of m-xylene on photocatalytic paints
}

Julien Morin, Adrien Gandolfo, Brice Temime-Roussel, Gregory Brochard, Virginie Bergé, Sasho Gligorovski, Henri Wortham

\section{To cite this version:}

Julien Morin, Adrien Gandolfo, Brice Temime-Roussel, Gregory Brochard, Virginie Bergé, et al.. Key parameters influencing the uptake of m-xylene on photocatalytic paints. Building and Environment, 2020, 179, pp.106979. 10.1016/j.buildenv.2020.106979 . hal-02733482

\section{HAL Id: hal-02733482 \\ https://hal.science/hal-02733482}

Submitted on 2 Jun 2020

HAL is a multi-disciplinary open access archive for the deposit and dissemination of scientific research documents, whether they are published or not. The documents may come from teaching and research institutions in France or abroad, or from public or private research centers.
L'archive ouverte pluridisciplinaire HAL, est destinée au dépôt et à la diffusion de documents scientifiques de niveau recherche, publiés ou non, émanant des établissements d'enseignement et de recherche français ou étrangers, des laboratoires publics ou privés. 


\section{Key parameters influencing the uptake of $m$-xylene on photocatalytic paints}

2 Julien Morin ${ }^{\mathrm{a}, *}$, Adrien Gandolfo ${ }^{\mathrm{a}, * \dagger}$, Brice Temime-Roussel $^{\mathrm{a}}$, Gregory Brochard ${ }^{\mathrm{b}}$, Virginie

3 Bergé $^{\mathrm{b}}$, Sasho Gligorovski ${ }^{\mathrm{c}}$, Henri Wortham ${ }^{\mathrm{a}, \sharp}$

4

$5 \quad$ a Aix Marseille Univ, CNRS, LCE, UMR 7376, 13331 Marseille, France

$6 \quad{ }^{\mathrm{b}}$ ALLIOS, 185 chemin de St Lambert, 13821 La penne sur Huveaune, France

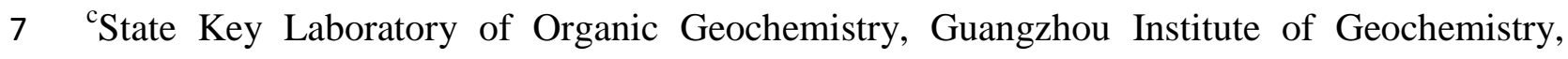

8 Chinese Academy of Sciences, Guangzhou 510 640, China

9 *The two authors have contributed equally to the study

$10{ }^{\dagger}$ Present Adress : AtmoSud, Route de la vierge, 13500 Martigues, France

$11{ }^{\ddagger}$ Corresponding authors: e-mail: henri.wortham@univ-amu.fr, Phone: +33 413551039

12 E-mail: julien.morin@univ-amu.fr; Phone: +33 647308629 


\section{ABSTRACT}

2 Given the toxic nature of many volatile organic compounds (VOCs) present within indoor

3 environments, it is necessary to develop new materials to eliminate them. Photocatalytic

4 paints represent a promising technology to remove the indoor pollutants but they are not

5 optimised yet. Here we evaluate the capacities of one conventional white-wall paint, three

6 photocatalytic paints containing 3.5, 5.25 and $7 \%$ of nano- $\mathrm{TiO}_{2} \mathrm{PC} 500$, and two

7 photocatalytic paints with a hybrid cellulose nanocrystals-nano- $\mathrm{TiO}_{2}\left(\mathrm{CNC}-\right.$ nano- $\left.\mathrm{TiO}_{2}\right)$ to

8 eliminate $m$-xylene from the indoor environment. In particular, we assess the impact of nano-

$9 \mathrm{TiO}_{2}$ content, light intensity, relative humidity $(\mathrm{RH})$, surface temperature $(288-320 \mathrm{~K})$ and pigment volume concentration (PVC) on uptake of $m$-xylene. Uptake coefficients of $m$-xylene increase by a factor 3,5 and 3 , respectively, as a function of nano- $\mathrm{TiO}_{2}$ content, irradiance and PVC. In contrast, uptakes of $m$-xylene decrease for a factor of 2 and 3 , as a function of $\mathrm{RH}$, and surface, suppressing the photocatalytic activity. The addition of $\mathrm{CNC}$-nano- $\mathrm{TiO}_{2}$ in the binder induces limited binder degradation. These are very promising results which may help to improve the performances of indoor photocatalytic paints aimed to eliminate indoor airborne pollutants.

Keywords: Indoor Air; Photocatalysis; Uptake coefficient; Cellulose Nanocrystals; Flow Tube; PTR-MS 


\section{INTRODUCTION}

Volatile organic compounds (VOCs) represent ubiquitous indoor air pollutants [1,2]. Some VOCs are known to cause human health effects and VOC compounds, such as formaldehyde, benzene, dichloromethane, have been identified as carcinogens [3]. The indoor sources of VOCs are numerous and include emissions from building itself, decorative material (paints, vanishes...), furniture, inhabitants' activities (cooking, smoking...) and domestic cleaning products, among others. Recent studies carried out in France [4] and in Europe [5] shown a VOCs indoor-to-outdoor environment concentration ratios up to 14.3. In occidental countries, humans spend on average over $90 \%$ of their lifetime within indoor settings [6]. Based on these two observations, it is necessary to develop methods to reduce VOCs levels in order to improve indoor air quality. This approach include different techniques such as biofiltration, adsorption, condensation, incineration and photocatalytic oxidation (PCO) [7-9]. The photocalytic system allows to oxidize, as well as reduce, air pollutants adsorbed on semiconductor surface. PCO is intensively studied and considered as a promising technology [10] to improve indoor air quality.

Benzene, Toluene, Ethylbenzene and $o-m-p$ Xylenes also called BTEX have been extensively studied in indoor air because of their toxicity [11-14] and their high measurements frequency. For instance, Hazrati et al .[15] summarized house BTEX concentrations in different countries. Their concentrations range as 1-5 ppb, 3-10 ppb, 1-5 ppb and 2-15 ppb for benzene, toluene, ethylbenzene and xylenes, respectively. The main sources of xylenes are vehicles exhaust [16].

The degradation of $m$-xylene has been studied on different supports as a function of Relative Humidity (RH) [17-20], irradiance [21] and nano- $\mathrm{TiO}_{2}$ content [21]. To the best of our knowledge, there is no previous studies focused on the influence of surface temperature, aging and Pigment Volume Concentration (PVC) of photocatalytic materials on the $m$-xylene 
1 degradation. The study of Strini et al. [21] has shown the increase of the photocatalytic

2 activity with increase of light intensity. The improved photocatalytic ability was also observed 3 with increase of nano- $\mathrm{TiO}_{2}$ content [21]. Jo et al. [19] observed no impact of $\mathrm{RH}$ on 4 photocatalytic activity whereas two other studies showed an influence of $\mathrm{RH}$ on 5 photocatalytic efficiency. At low concentration of $m$-xylene (46 ppb) [18] a decrease of 6 photocatalytic activity has been observed with increase of RH. At high concentration 7 (460 ppb) of $m$-xylene [18] an increase between 0 and $45 \%$ of RH and a decrease above $45 \%$ of RH; of photocatalytic activity have been observed. These different studies have been performed on photocatalytic thin films [19], glass fibers [17] and cement mortars [18,21] but never on photocatalytic paints. Tryba et al. [22] have studied the degradation of benzo[a]pyrene by photocatalytic paints but they have not assessed the impact of different environmental and physical parameters on photocatalytic efficiency to eliminate indoor VOCs. Additional studies are recommended to improve the knowledge o, this matter.

In this study we have chosen $m$-xylene as a model compound because: 1 ) it is commonly observed in indoor environment [15], 2) it is not emitted by the studied paints [23] thus avoiding experimental artefacts, 3) it presents hazardous effects on human health (neurologic effects, digestive disorder, irritation...) [14] and 4) it is not an easily degradable compound due to the relative stability of aromatic rings with respect to its oxidation and reduction process.

In the present work, the uptake coefficients of $m$-xylene on various paints (non-photocatalytic, hereafter, reference paint and photocatalytic paints) were determined under different experimental conditions in presence of UV irradiation. The influence of key parameters driving the reaction was evaluated by the comparative approach. The influence of environmental parameters (surface temperature, $\mathrm{RH}$, irradiance intensity) as well as paint 
1 physical parameters (photocatalyst type and content, paint aging and paint porosity) on $m$ -

2 xylene degradation have been examined.

3

4

5

\section{MATERIALS AND METHODS}

\subsection{Experimental study}

A double wall flow tube photoreactor was connected to High Sensitivity-Proton Transfer Reaction-Mass Spectrometry (HS-PTR-MS) (IONICON Analytik, Austria). The operational procedure of flow tube photoreactor has been described in detail by Gandolfo et al. [24] and Morin et al. [23]. The schematic diagram of the experimental setup is presented in Figure 1. Experimental details that are particularly relevant to this work are given below.

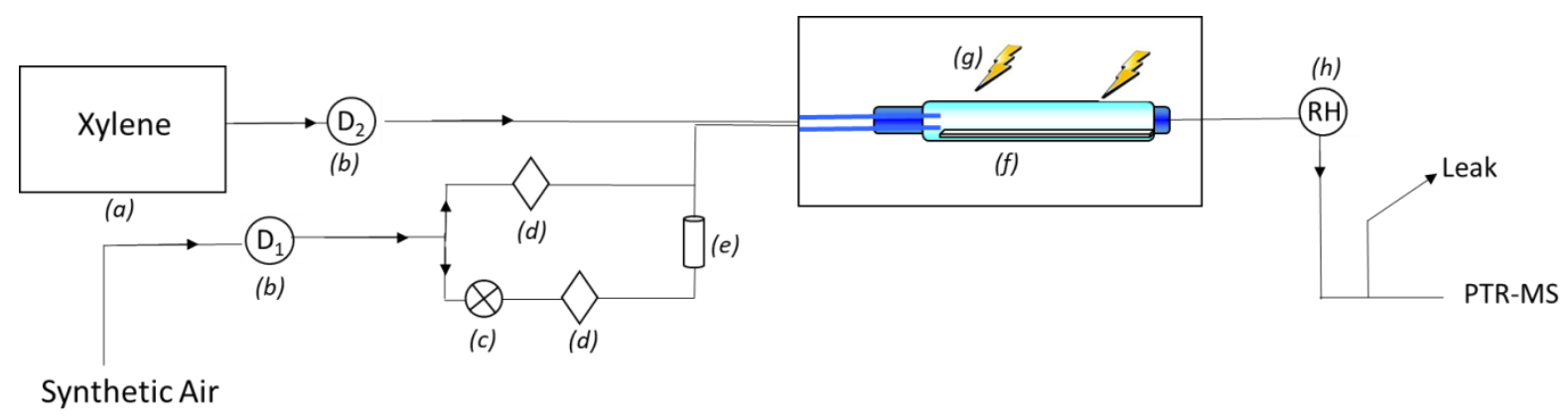

Figure 1: Schematic illustration of the experimental setup. Permeation oven (a), mass flow controller (b), on/off valve (c), needle valve (d), relative humidity system (e), reactor + glass paint (f), UV-lamps (g), RH probe + hygrometer (h).

The flow tube is made of borosilicate glass with an internal volume of $131 \mathrm{~cm}^{3}$ and was coupled to a temperature-controlled circulating bath (RC6 LAUDA, Germany) which allows to perform the experiments at different surfaces temperatures between 288 and $320 \mathrm{~K}( \pm 1 \mathrm{~K})$. Experiments were carried out at 1 atm total pressure of synthetic air (Linde Gas, France, $>99.999$ stated purity). The glass plate recovered by the paint was introduced into the flow tube reactor with the painted side upward oriented. Inside the flow tube, a glass made 
movable injector was inserted into the flow tube to inject $m$-xylene and vary the residence time and thus asses the kinetics of the heterogeneous reactions.

The flow tube reactor was placed in a stainless steel box with four UV fluorescent lamps (Philips TL-D 18W Actinic BL, 340-400 nm, $\lambda_{\max }=368 \mathrm{~nm}$, length $=60 \mathrm{~cm}$ ) mounted side by side on the upper part of the box above the flow tube photoreactor. The UV-lamps simulated UV solar irradiation and could be operated individually. The spectral irradiance of the UV lamps used in this work had been determined previously [25]. The integrated spectral irradiance $(340<\lambda<400 \mathrm{~nm})$ was estimated to be $4.9,8.8,13.5$ and $18.6 \mathrm{~W} \mathrm{~m}^{-2}$ for $1,2,3$ and 4 lamps, respectively.

Gaseous m-xylene was generated using a gas-phase generator (PUL 200, Saint Chamas, France). A sealed permeation cell consisting of a Teflon tube (perfluoroalkoxy, $4.0 \times 6.4 \mathrm{~mm}$, $8 \mathrm{~cm}$ long) filled with pure $m$-xylene (Sigma-Aldrich, $\geq 99.5 \%$ ) was used to generate gasphase $m$-xylene. The permeation cell was placed in the oven chamber of the gas-phase generator. At the exit of the oven, a constant flow of $10 \mathrm{sccm}$ (Brooks SLA, Series mass flow controller, in the range $0-10 \mathrm{sccm}, \pm 1 \%$ stated accuracy) of gaseous $m$-xylene was allowed to enter the injector. A sheath synthetic air flow of $190 \mathrm{sccm}$ (Brooks SLA, Series mass flow controller, in the range $0-500 \mathrm{sccm}, \pm 1 \%$ stated accuracy) was allowed to enter the flow tube to dilute the $m$-xylene flow. To better simulate realistic indoor concentration, all experiments were carried out at $\sim 50 \mathrm{ppb}$ of $m$-xylene.

Relative humidity was adjusted by splitting the sheath synthetic air flow into a dry flow and a humidified flow. For all the experiments, the RH was measured online at the exit of reactor by a hygrometer "Hygrolog NT2" (Rotronic) with "HygroClip SC04" probe and ranged from 2 to $70 \%$ with accuracy of $\pm 1.5 \%$.

The $m$-xylene mixing ratio was measured in real time by a HS-PTR-MS by following its 
1 protonated molecular pic $(\mathrm{m} / \mathrm{z}$ 107). Formaldehyde $(\mathrm{m} / \mathrm{z}, 31)$, acetaldehyde $(\mathrm{m} / \mathrm{z} 45)$ and acetone $(\mathrm{m} / \mathrm{z} 5 \mathrm{59})$ were also monitored as intermediates by-products. The HS-PTR-MS high time resolution (10 seconds) allows us to measure rapid changes in gas phase concentrations. The drift temperature, drift voltage and a pressure were fixed at $333 \pm 1 \mathrm{~K}, 500 \pm 1 \mathrm{~V}$ and $2.02 \pm 0.01$ mbar respectively, that corresponded to the $\mathrm{E} / \mathrm{N}$ value of 124 Townsend (1 Townsend $=10^{-17} \mathrm{~V} \mathrm{~cm}^{2}$ ), where $\mathrm{E}$ is the electric field $\left(\mathrm{V} \mathrm{cm}^{-1}\right)$ and $\mathrm{N}$ is the ambient air number density within the drift tube $\left(\mathrm{cm}^{-3}\right)$. The calculation of VOCs mixing ratio and surface emission fluxes is described in detail by Morin et al. [23].

\subsection{Preparation of paints}

Paints were formulated and produced by the paint manufacturer ALLIOS (Marseille, France). TITANE PC 500 in anatase form with $85 \%$ of $\mathrm{TiO}_{2}$ nanoparticle was used as a photocatalyst. TITANE PC 500 represents ultrafine $\mathrm{TiO}_{2}$ powder with specific area of $350 \mathrm{~m}^{2} \mathrm{~g}^{-1}$ and particle size between 3 and $5 \mathrm{~nm}$. A mixture of ground additives (slurry) was prepared with $35 \%(w / w)$ active nanosized $\mathrm{TiO}_{2}$. Then, other paint constituents (architectural constituent of paints, i.e., $\mathrm{CaCO}_{3}$ and micrometric $\mathrm{TiO}_{2}$ ) were mixed with 10,15 and $20 \%$ of the slurry to reach 3.5, 5.25 and $7 \%(\mathrm{w} / \mathrm{w})$ of photocatalytic active $\mathrm{TiO}_{2}$ nanoparticles, respectively. The $\mathrm{TiO}_{2}$ nanoparticles are not present in the reference paint. The prepared paint is applied on the glass plate by dint of a spiral film applicator. This methodology allows to obtain controlled and reproducible wet paint thickness of $100 \mu \mathrm{m}$. Then, the paints were dried in an oven ventilated by clean air during 21 days at $296 \mathrm{~K}$ and $55 \%$ of $\mathrm{RH}$ resulting in a uniform thickness film of $40 \mu \mathrm{m}$.

To investigate the impact of porosity on the degradation rates, three paints with different porosities were developed. To assess the paint porosity, it was necessary to introduce the Critical Pigment Volume Concentration (CPVC). CPVC is a specific Pigment Volume Concentration (PVC) in which the voids between the solid particles (structural agents and 
1 pigments) are just filled with the binder [26]. The PVC and CPVC are linked to the paint

2 porosity as follows:

$$
\text { porosity }(\%)=1-\frac{C P V C}{P V C}
$$

The value of CPVC is not clearly known but it can be estimated between $50-60 \%$ (manufacturer information). For this study, three paints with PVC of 53, 72 and $80 \%$ were considered. The calculation of PVC were shown previously by Gandolfo et al. [26].

In another series of paints, the standard nano- $\mathrm{TiO}_{2}$ (PC 500) was replaced by a hybrid cellulose nanocrystals-nano- $\mathrm{TiO}_{2}\left(\mathrm{CNC}-\mathrm{TiO}_{2}\right)$ in the paint preparation to increase nano- $\mathrm{TiO}_{2}$ dispersion in the slurry. This addition allowed to form hybrid $\mathrm{CNC}-\mathrm{TiO}_{2}$ nanoparticles which may improve the photocatalytic activity of $\mathrm{TiO}_{2}$. The aim of this hybrid nanoparticle was to reduce the quantity of nano- $\mathrm{TiO}_{2}$ embedded in the paint and keeps high photocatalytic efficiency. In this work, two photocatalytic paints with 0.16 and $0.23 \%$ (w/w) of nano- $\mathrm{TiO}_{2}$ have been studied. Photocatalytic paints with hybrid $\mathrm{CNC}$-nano- $\mathrm{TiO}_{2}$ and the photocatalytic paint with $3.5 \%$ of nano- $\mathrm{TiO}_{2} \mathrm{PC} 500$ have been aged in a accelerated weathering chamber for 500 hours and 1000 hours according to the ISO norm 16474-3 [27,28]. Aging of 500 hours correspond to an important aging of paint and an aging of 1000 hours correspond to a paint of end-of-life.

The paints, except CNC paints, were applied on one side of glass plates that were $29 \mathrm{~cm}$ long and $1.9 \mathrm{~cm}$ wide according to a standard operating procedure developed by the manufacturer ALLIOS [29]. The CNC paints were applied on Leneta supports that were $29 \mathrm{~cm}$ long and $1.9 \mathrm{~cm}$ wide. To assure proper fit of the Leneta surface into the reactor, the later were fixed on a glass plate with wire to both ends prior to kinetic experiments.

\subsection{Kinetic measurements}

The aim of this study was to evaluate the uptake coefficients $(\gamma)$ of $m$-xylene on reference 
1 paint and on photocatalytic paints. The uptake coefficients were determined using the

2 following equation [30]:

3

4 where $\mathrm{k}_{1 \mathrm{st}}$ is the pseudo-first order rate constant of $m$-xylene loss $\left(\mathrm{s}^{-1}\right)$, $\omega$ is the mean

5 molecular velocity $\left(\mathrm{cm} \mathrm{s}^{-1}\right)$ and V/S represents the ratio of the volume of the reactor to surface

6 of the glass plate $(\mathrm{cm})$

7

$\mathrm{k}_{1 \mathrm{st}}$ was determined by the slope of $\ln \left(\mathrm{C}_{0} / \mathrm{C}_{\mathrm{x}}\right)$ plotted as a function of the residence time $(\mathrm{t}) . \mathrm{C}_{0}$ is the initial concentration of $m$-xylene in position $\mathrm{P}_{0}$. In this case, gaseous $m$-xylene is not exposed to the paint. $\mathrm{C}_{\mathrm{x}}$ is the concentration of $m$-xylene at different positions from $\mathrm{P}_{1}$ to $\mathrm{P}_{4}$ (Table 1). The difference of concentrations between $\mathrm{C}_{0}$ and $\mathrm{C}_{\mathrm{x}}$ corresponds to amount of $m$ xylene consumed by its reaction with the paint surface. Each position was hold during about 30 min to get stabilized signal and reliable measuring points. After each position change, the injector was pushed in position $\mathrm{P}_{0}$ to go back to the initial conditions. The variation of the concentration in function of the injector position enabled to calculate the pseudo-first order rate constant $[25,26,31,32]$.

Table 1: Distance to the end of reactor $(\mathrm{cm})$, exposed paint surface $\left(\mathrm{cm}^{2}\right)$ and contact time (s) between gaseous $m$-xylene and paint as a function of movable injector position.

\begin{tabular}{|c|c|c|c|}
\hline Position & Distance (cm) & Exposed surface $\left.\mathbf{( c m}^{\mathbf{2}}\right)$ & Contact time (s) \\
\hline $\mathrm{P}_{0}$ & 0 & 0 & 0 \\
\hline $\mathrm{P}_{1}$ & 4 & 7.6 & 5.4 \\
\hline $\mathrm{P}_{2}$ & 8 & 15.2 & 10.9 \\
\hline $\mathrm{P}_{3}$ & 15 & 28.5 & 20.4 \\
\hline $\mathrm{P}_{4}$ & 22 & 41.8 & 29.9 \\
\hline
\end{tabular}

A typical experiment and the assessment of pseudo-first order rate constant of $m$-xylene are presented in SI (Figure S1-S2). Blank experiments have been performed to ensure that no wall loss occurs during experiments and corrections have been applied to the obtained results.

$$
\gamma=\frac{4 k_{1 s t}}{\omega} \frac{V}{S}
$$


1 The Cooney-Kim-Davis (CKD) method was used to correct the uptake coefficients from

2 diffusion limitation in the flow tube $[33,34]$. Under the applied experimental conditions, the

3 estimated correction by CKD was less than $10 \%$.

4 The experimental conditions are given in Table 2.

5 Table 2: Experimental conditions

\begin{tabular}{|c|c|c|c|c|c|}
\hline Experiments & $\begin{array}{c}\text { Nano-TiO } \\
\text { content w/w (\%) }\end{array}$ & $\begin{array}{c}\text { Surface } \\
\text { temperature } \\
(\mathbf{K})\end{array}$ & $\mathbf{R H}(\boldsymbol{\%})$ & $\begin{array}{c}\text { Irradiance } \\
\left(\mathbf{W ~ m ~}^{-2}\right)\end{array}$ & PVC (\%) \\
\hline 1 & $0,3.5,5.25$ and 7 & 296 & 40 & 8.8 & 72 \\
\hline 2 & 0 and 7 & 298 & 40 & $0-18.6$ & 72 \\
\hline 3 & 7 & 295 & $0-70$ & 8.8 & 72 \\
\hline 4 & 7 & $288-320$ & 37 & 8.8 & 72 \\
\hline 5 & 7 & 296 & 40 & 8.8 & $53-80$ \\
\hline 6 & $\begin{array}{c}\text { NCC : 0.16, 0.23 } \\
\text { PC 500 }: 3.5\end{array}$ & 298 & 40 & 8.8 & NA* $^{*}$ \\
\hline
\end{tabular}

$6 *$ Not available

\section{RESULTS AND DISCUSSION}

8

\subsection{Nano- $\mathrm{TiO}_{2}$ content}

9 The influence of the quantity of nano- $\mathrm{TiO}_{2}$ on the uptake coefficients of $m$-xylene is presented 10 in Figure 2. 
2 Figure 2: The effect of nano- $\mathrm{TiO}_{2}$ content on uptake coefficients of $m$-xylene. $m$-xylene 3 mixing ratio: $50 \mathrm{ppb}$, temperature: $296 \mathrm{~K}, \mathrm{RH}: 40 \%$, light intensity: $8.8 \mathrm{~W} \mathrm{~m}^{-2}$, PVC: $72 \%$, 4 aging: 0 hour, nano- $\mathrm{TiO}_{2} \mathrm{PC} 500$. The line represents the linear regression. The errors bars are 5 derived from uncertainties associated to uptake coefficient.

6

7

The uptake coefficient for the reference paint is $(7.3 \pm 2.3) \cdot 10^{-7}$ and increases up to $(2.0 \pm 0.5) \cdot 10^{-6}$ for the photocatalytic paint at $7 \%$ of nano- $\mathrm{TiO}_{2}$. The linear relation between uptake coefficient and nano- $\mathrm{TiO}_{2}$ content is described as follows:

$$
\gamma=(1.8 \pm 0.2) \times 10^{-7} \times \text { nanoTiO }_{2} \text { content }+(7.1 \pm 0.7) \times 10^{-7} \quad(\text { Eq. } 3)
$$

When the nano- $\mathrm{TiO}_{2}$ quantity increases, the quantity of $\mathrm{OH}$ radicals produced increases [35] on the paint surface which accelerates the degradation of $m$-xylene. For this reason, the increase of quantity of $\mathrm{TiO}_{2}$ nanoparticles from 0 to $7 \%$, improves the removal of $m$-xylene by a factor of 3 which is in agreement with the reported factor of 4 in a previous study focused on removal of $o$-xylene [21] on cementitious photocatalytic materials.

Due to improved removal efficiency towards $m$-xylene, the photocatalytic paint containing $7 \%$ of nano- $\mathrm{TiO}_{2}$ was used to assess the impact of $\mathrm{RH}$, surface temperature, light intensity and pigment volume concentration.

\subsection{UV irradiation intensity}

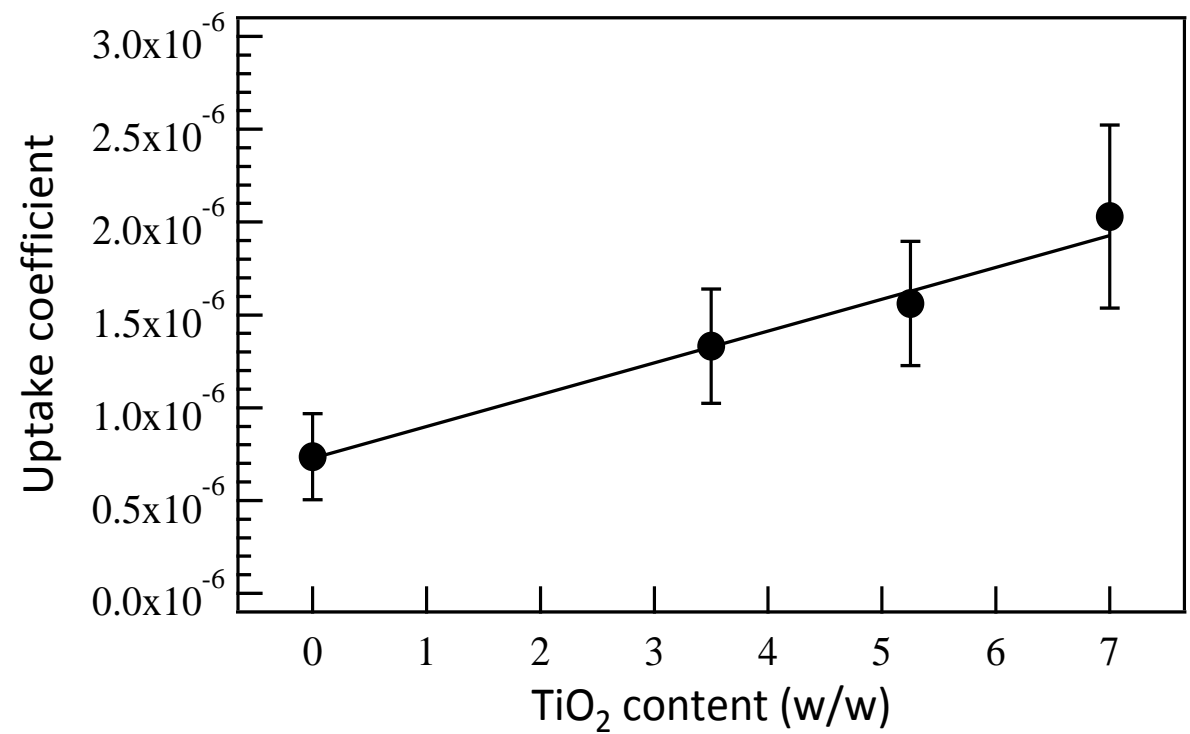


1 The effect of light intensity on the uptake coefficients of $m$-xylene on reference paint and on

2 photocatalytic paint containing $7 \%$ of nano- $\mathrm{TiO}_{2}$ has been evaluated (Figure 3).

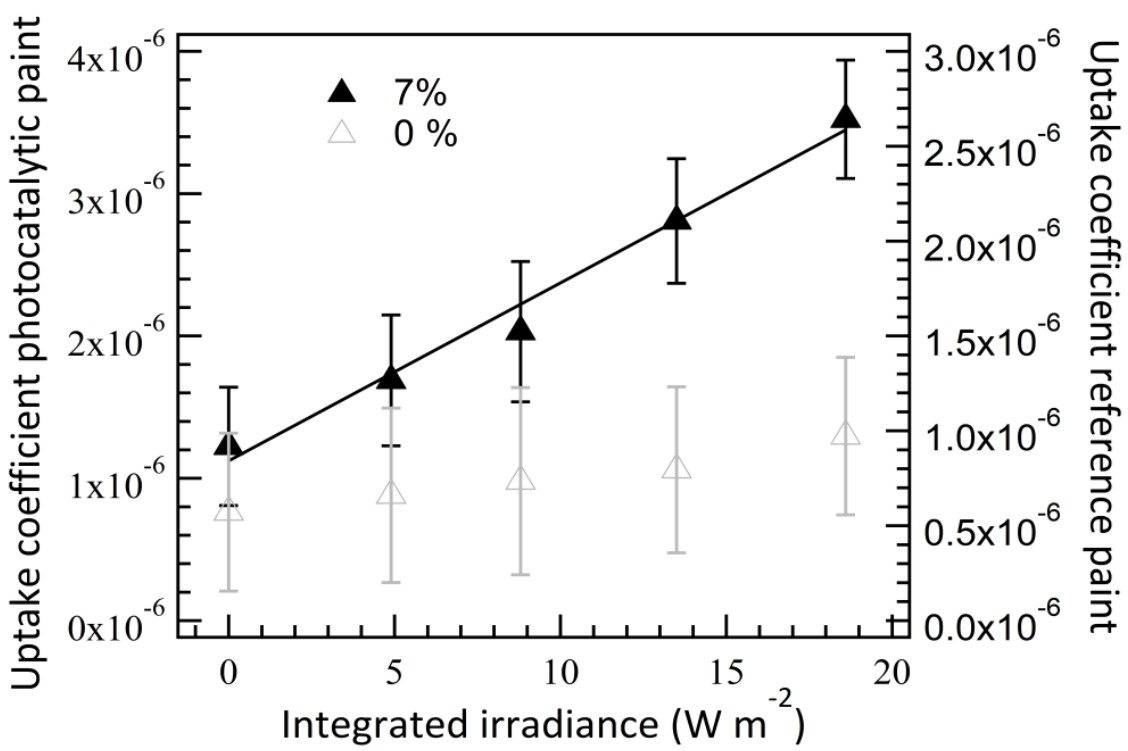

$4 \quad$ Figure 3: The effect of light intensity on uptake coefficients of $m$-xylene. $m$-xylene mixing 5 ratio: $50 \mathrm{ppb}$, temperature: $298 \mathrm{~K}, \mathrm{RH}: 40 \%$, PVC: $72 \%$, aging: 0 hour. Photocatalytic paint: $67 \%$ nano- $\mathrm{TiO}_{2}$ PC 500 (filled triangle) and reference paint (empty triangle). The line 7 represents the linear regression of the plotted data. The errors bars are derived from 8 uncertainties associated to uptake coefficient.

The uptakes of $m$-xylene on a reference paint only slightly increase with the variation of spectral irradiance from $(5.7 \pm 1.0) \cdot 10^{-7}$ in dark up to $(9.7 \pm 1.4) \cdot 10^{-7}$ at $18.6 \mathrm{~W} \mathrm{~m}^{-2}$. In contrast, the uptake of $m$-xylene on a photocatalytic paint with $7 \% \mathrm{TiO}_{2}$ nanoparticles increases for a factor of 3 , from $(1.2 \pm 0.4) \cdot 10^{-6}$ in dark up to $(3.5 \pm 0.4) \cdot 10^{-6}$ under maximum light irradiation of $18.6 \mathrm{~W} \mathrm{~m}^{-2}$. The linear relation depicted in plot is described by the equation (Eq.4):

$$
\gamma=(1.3 \pm 0.1) \times 10^{-7} \times \text { Irradiance }\left(W^{-2}\right)+(1.1 \pm 0.1) \times 10^{-6}
$$

The increase of light intensity leads to enhanced formation of $\mathrm{OH}$ radicals formed on the paint surface which in turn leads to accelerated degradation of $m$-xylene [36].

A similar trend of linear increase of the degradation of toluene on glass fiber as a function of light intensity was observed by Palau et al. [17] and the degradation of $o$-xylene on 
1 cementitious material by Strini et al. [21]. In their work, an increase by a factor 2.5 was

2 observed that is in agreement with the factor 2 measured here.

3 These results show that the experiments were performed under light unsaturation and that the

4 surface chemical reaction is the rate-determining step.

The impact of the RH on the uptake coefficients is shown in Figure 4.

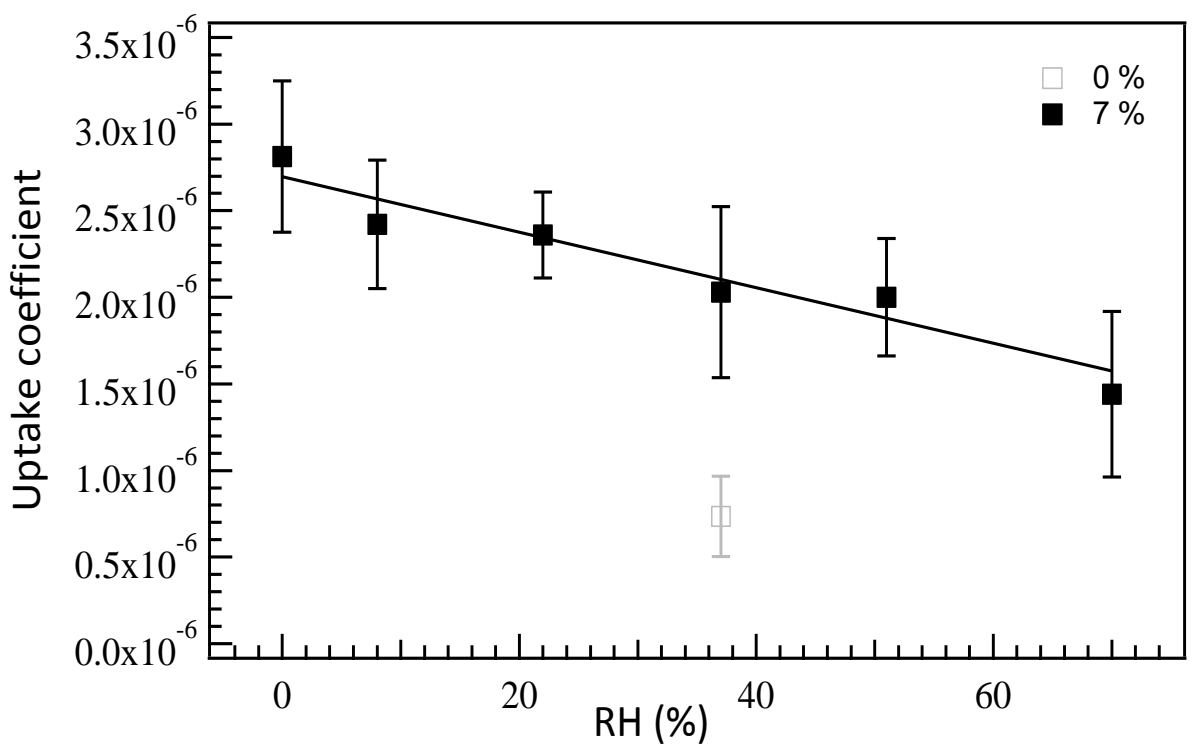

8 Figure 4: The effect of $\mathrm{RH}$ on uptake coefficients of $m$-xylene. $m$-xylene mixing ratio: $950 \mathrm{ppb}$. Photocatalytic paint: $7 \%$ nano- $\mathrm{TiO}_{2}$ PC 500 (filled square) and reference paint (empty square), light intensity: $8.8 \mathrm{~W} \mathrm{~m}^{-2}$, temperature: $295 \mathrm{~K}$, PVC: $72 \%$, aging: 0 hour. The line represents the linear regression. The errors bars are derived from uncertainties associated to uptake coefficient.

14 The uptake coefficient of $m$-xylene is $(2.8 \pm 0.4) \cdot 10^{-6}$ at $2 \% \mathrm{RH}$ and decreased up to $15(1.4 \pm 0.5) \cdot 10^{-6}$ at $70 \% \mathrm{RH}$. The linear relation is described by the following mathematical equation (Eq.5): 
1 The decrease of the uptake by a factor 2 is in good agreement with the observed decreasing

2 conversion ratio (46 ppb of $m$-xylene) by a factor of 1.5 as the $\mathrm{RH}$ increased from 0 to $70 \%$

3 [18]. This phenomenon can be ascribed to a competitive adsorption between water and $m$ -

4 xylene molecules on the paint surface. At low humidity, the adsorption competition on

5 semiconductor surface is limited which allowed the more efficient degradation of $m$-xylene.

6 As the humidity increases, absorbed water molecules on nano- $\mathrm{TiO}_{2}$ competes with the $m$ -

7 xylene adsorption. Consequently, the photocatalytic heterogeneous reactivity is reduced at 8 high relative humidity [8].

9 At very high mixing ratio of $m$-xylene (460 ppb), Martinez et al. [18] observed an increased removal efficiency of $m$-xylene at $45 \% \mathrm{RH}$ which further decreased for $\mathrm{RH}$ between 45 and $80 \%$. Such increase of removal efficiency of xylene $(230 \mathrm{ppb})$ on photocatalytic materials has also been observed by Palau et al. [17] for RH comprised between 4 and $70 \%$.

\subsection{Surface temperature}

14 To the best of our knowledge, the impact of surface temperature on the uptake coefficients of $m$-xylene has not been studied previously. The surface temperature varied between 288 and 320 K (Figure 5). 


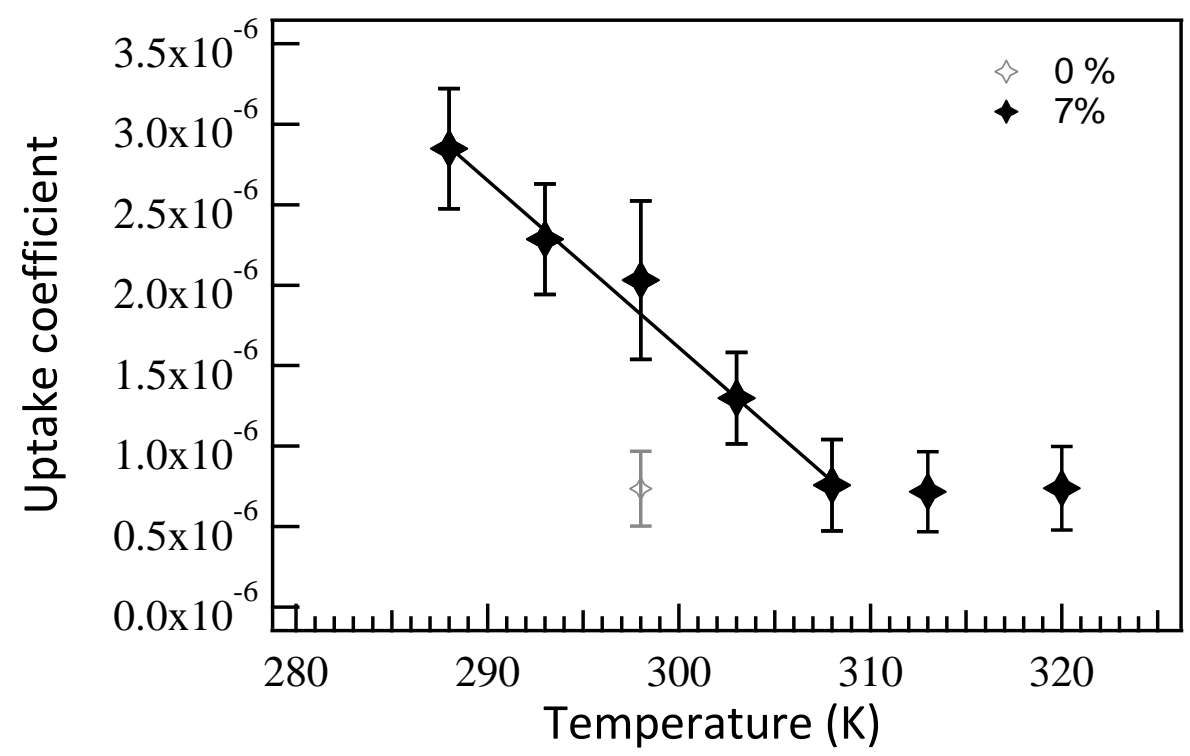

2 Figure 5: The effect of surface temperature on uptake coefficients of $m$-xylene. $m$-xylene 3 mixing ratio: $50 \mathrm{ppb}$. Photocatalytic paint: $7 \%$ nano- $\mathrm{TiO}_{2} \mathrm{PC} 500$ (filled lozenge) and 4 reference paint (empty lozenge), light intensity: $8.8 \mathrm{~W} \mathrm{~m}^{-2}, \mathrm{RH}: 37 \%$, PVC: $72 \%$, aging: 50 hour. The line represents the linear regression. The errors bars are derived from 6 uncertainties associated to uptake coefficient.

7

Figure 5 shows that the uptake coefficients of $m$-xylene decreased significantly as the temperature increases followed by a saturation effect. At $288 \mathrm{~K}$; the uptake coefficient is $(2.8 \pm 0.4) \cdot 10^{-6}$ and decreased up to $(7.6 \pm 2.9) \cdot 10^{-7}$ at $308 \mathrm{~K}$. At higher temperatures than $308 \mathrm{~K}$, the uptakes of $m$-xylene remain stable. For the range of temperatures between 288 and $308 \mathrm{~K}$, the solid line in Figure 5 represents the regression line which corresponds to the following equation (Eq.6):

$$
\gamma=-(1.0 \pm 0.1) \times 10^{-7} \times T(K)+(3.3 \pm 0.2) \times 10^{-5}
$$

The reduced removal efficiency of photocatalytic paint with $7 \% \mathrm{TiO}_{2}$ nanoparticles at higher temperatures can be ascribed to the reduced contact time between gaseous $m$-xylene and the paint surface. Namely, as the surface temperature increases $m$-xylene desorb more rapidly and thus decrease the contact time with the paint surface. In that way, the contact time becomes not sufficient to achieve the degradation process [37]. 
1 The uptakes of $m$-xylene for temperature range between 308 and $320 \mathrm{~K},(7.6 \pm 2.9) \cdot 10^{-7}$, fall in

2 the same range as the uptake of $m$-xylene on a reference paint, $(7.3 \pm 2.3) \cdot 10^{-7}$. Hence, the

3 observed plateau in Figure 5 indicates that at higher temperature than $308 \mathrm{~K}$, the removal of

$4 \quad m$-xylene is not driven by the photocatalytic process.

\subsection{Effect of pigment volume concentration (PVC)}

The removal of $m$-xylene was also evaluated on photocatalytic paints containing $7 \%$ of nano-

$7 \quad \mathrm{TiO}_{2}$ with PVC of $53 \%, 72 \%$ and $80 \%$ (Figure 6).

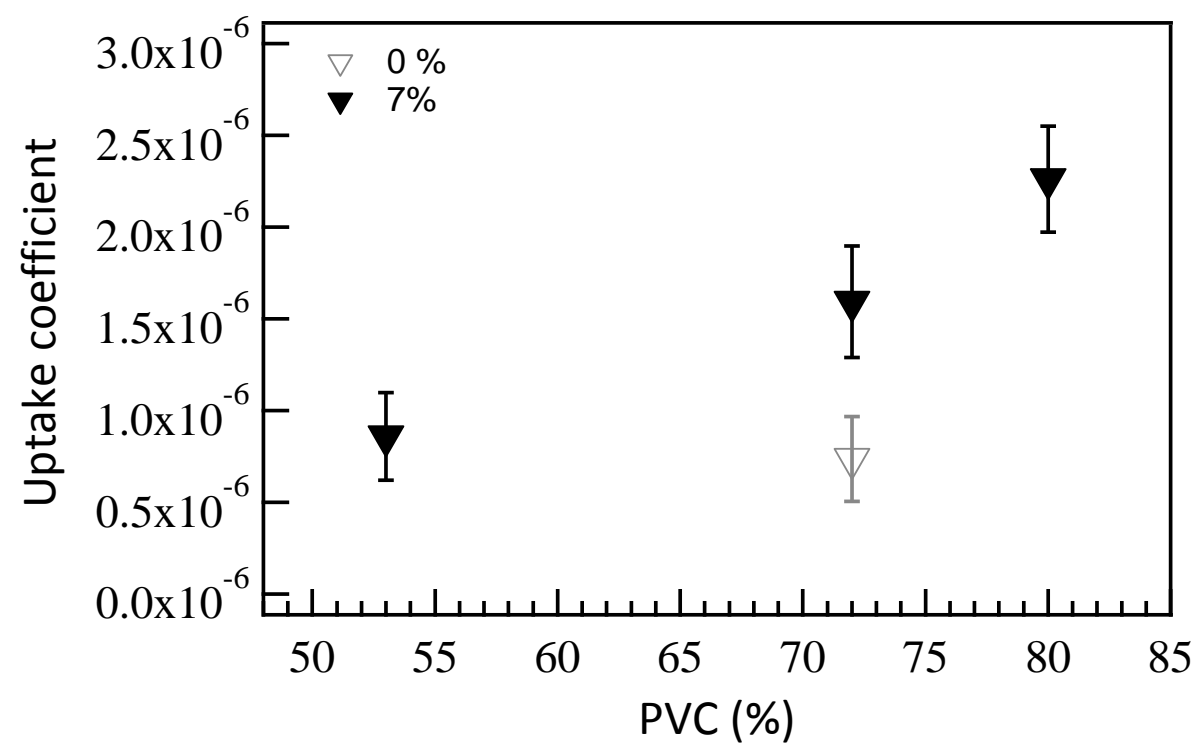

Figure 6: The effect of PVC on uptake coefficients of $m$-xylene. $m$-xylene mixing ratio: 50 ppb. Photocatalytic paint: $7 \%$ nano- $\mathrm{TiO}_{2}$ PC 500 (filled triangle) and reference paint (empty triangle), temperature: $296 \mathrm{~K}$, light intensity: $8.8 \mathrm{~W} \mathrm{~m}^{-2}, \mathrm{RH}: 37 \%$, aging: 0 hour. The errors bars are derived from uncertainties associated to uptake coefficient.

The uptake coefficients of $m$-xylene increase from $(8.6 \pm 2.4) \cdot 10^{-7}$ to $(2.3 \pm 0.3) \cdot 10^{-6}$ as the PVC increases from 53 to $80 \%$.

This increase of photocatalytic efficiency towards the removal of $m$-xylene can be ascribed to the fact that the increase of the porosity allows gaseous $m$-xylene to penetrate more easily through the paint and increase the contact time with the $\mathrm{OH}$ radicals which are generated by the irradiation of $\mathrm{TiO}_{2}$ nanoparticles [35]. Similarly, the increase of porosity on a commercial 
1 paint induced faster degradation of methyl ethyl ketone [38]. Jansson et al. [39] observed

2 accelerated degradation of formaldehyde by zeolite/TiO $\mathrm{T}_{2}$.

\subsection{CNC and aging}

The aging of three photocatalytic paints with various photocatalysts namely PC 500, CNC 0.5 and CNC 0.72 have been examined (Figure 7). The PC 500 represents the photocatalytic paint with $3.5 \%$ of nano- $\mathrm{TiO}_{2}$ and $\mathrm{CNC} 0.5$ and $\mathrm{CNC} 0.72$ paints contain 0.5 and $0.72 \%$ of hybrid cellulose nanocrystals (CNC) embedded in that paint that correspond to $0.16 \%$ and $0.23 \%$ of nano- $\mathrm{TiO}_{2}$, respectively. At first sight, the three paintings are identical in term of color and appearance regardless of the aging.

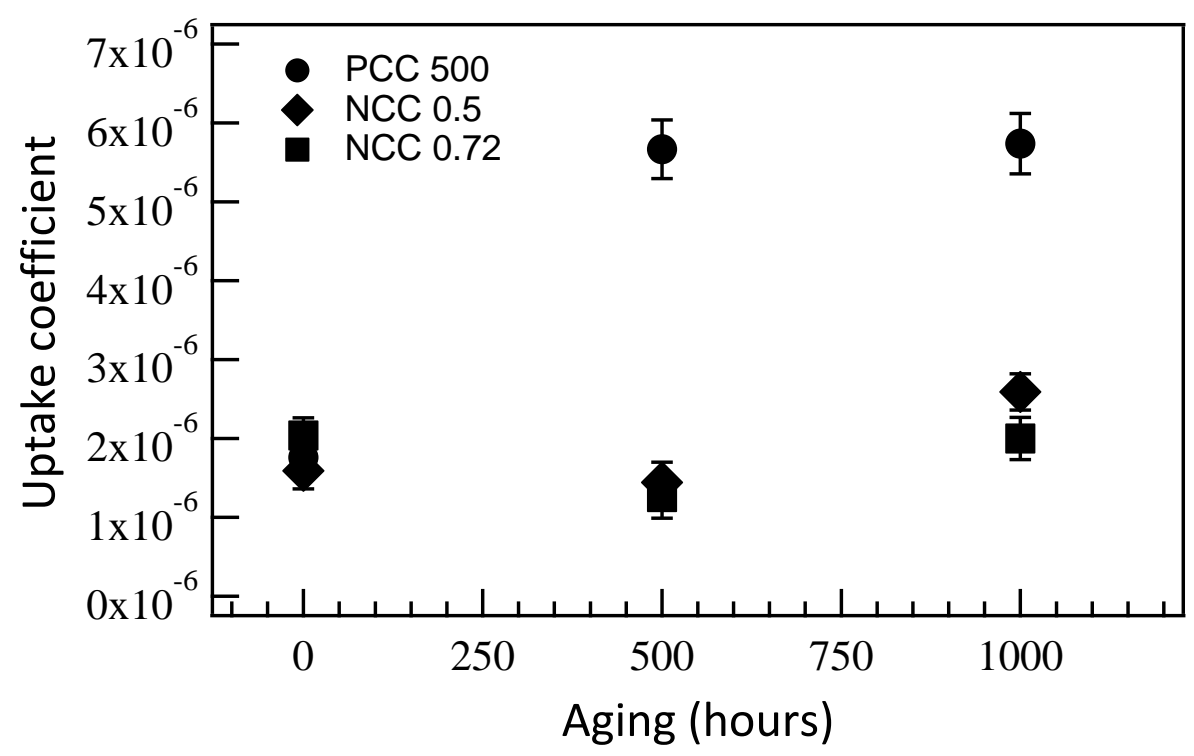

Figure 7: The effect of aging and photocatalyst on uptake coefficients of $m$-xylene. $m$-xylene: mixing ratio: $50 \mathrm{ppb}$, temperature: $296 \mathrm{~K}$; light intensity: $8.8 \mathrm{~W} \mathrm{~m}^{-2}, \mathrm{RH}: 37 \%$, paint PC 500 (circle), paint CNC 0.5 (lozenge) and paint CNC 0.72 (square). The errors bars are derived from uncertainties associated to uptake coefficient.

As shown on Figure 7, the uptake coefficients of $m$-xylene prior to aging of paints are similar for all the considered photocatalytic paints, $(1.7 \pm 0.3)-(2.0 \pm 0.3) \cdot 10^{-6}$. The addition of $\mathrm{CNC}$ in the paint formulation allowed to obtain similar effect on $m$-xylene degradation with 15 and 22 times lower nano- $\mathrm{TiO}_{2}$ quantity. 
1 The uptake coefficient of $m$-xylene on the paint PC 500 increased with the aging. After 500 or

21000 hours of aging, uptake coefficients are 3 times higher than for the fresh dry paint. On the

3 other hand, the aging has no effect on paint containing $\mathrm{CNC}^{-\mathrm{TiO}_{2}}$ hybrid nanoparticles. The

4 effect of aging on the binder of the paint was previously observed by Truffier-Boutry et al.

5 [28]. Once the binder was degraded, nano- $\mathrm{TiO}_{2}$ became more accessible to interact with $m$ -

6 xylene; hence, increased the removal efficiency. This hypothesis is confirmed by the results

7 presented in Figure 7 for the paint PC 500. However, the consumption of $m$-xylene is not

8 altered anymore after 500 hours of aging. This can be explain by the fact that after 500 hours

9 the paint binder is completely degraded and cannot further influence the photocatalytic 10 process.

11 For CNC paints, the uptake coefficients of $m$-xylene are independent of the aging process. Thus, the hybrid $\mathrm{CNC}$-nano- $\mathrm{TiO}_{2}$ plays a protective role of the binder, limiting the contact between the $\mathrm{OH}$ radicals and $m$-xylene.

\subsection{By-products formation}

In theory, the photocatalytic oxidation (PCO) should lead to the total mineralization of pollutants in $\mathrm{CO}_{2}$ and $\mathrm{H}_{2} \mathrm{O}$ [35]. Unfortunately, the $\mathrm{PCO}$ is known to produce volatile aldehydes and other partially oxidized by-products that can be released back to indoor air $[24,40]$. Formaldehyde, acetaldehyde, acetone, formic acid et acetic acid were produced due to the incomplete mineralization [41]. Formaldehyde and acetaldehyde have been observed as by-products during $p$-xylene degradation [42], whereas formaldehyde, acetaldehyde and acetone during toluene degradation [43]. The mixing ratios of $m$-xylene, formaldehyde, acetaldehyde and acetone in position $\mathrm{P}_{0}$ and $\mathrm{P}_{4}$ are shown in Figure 8. 


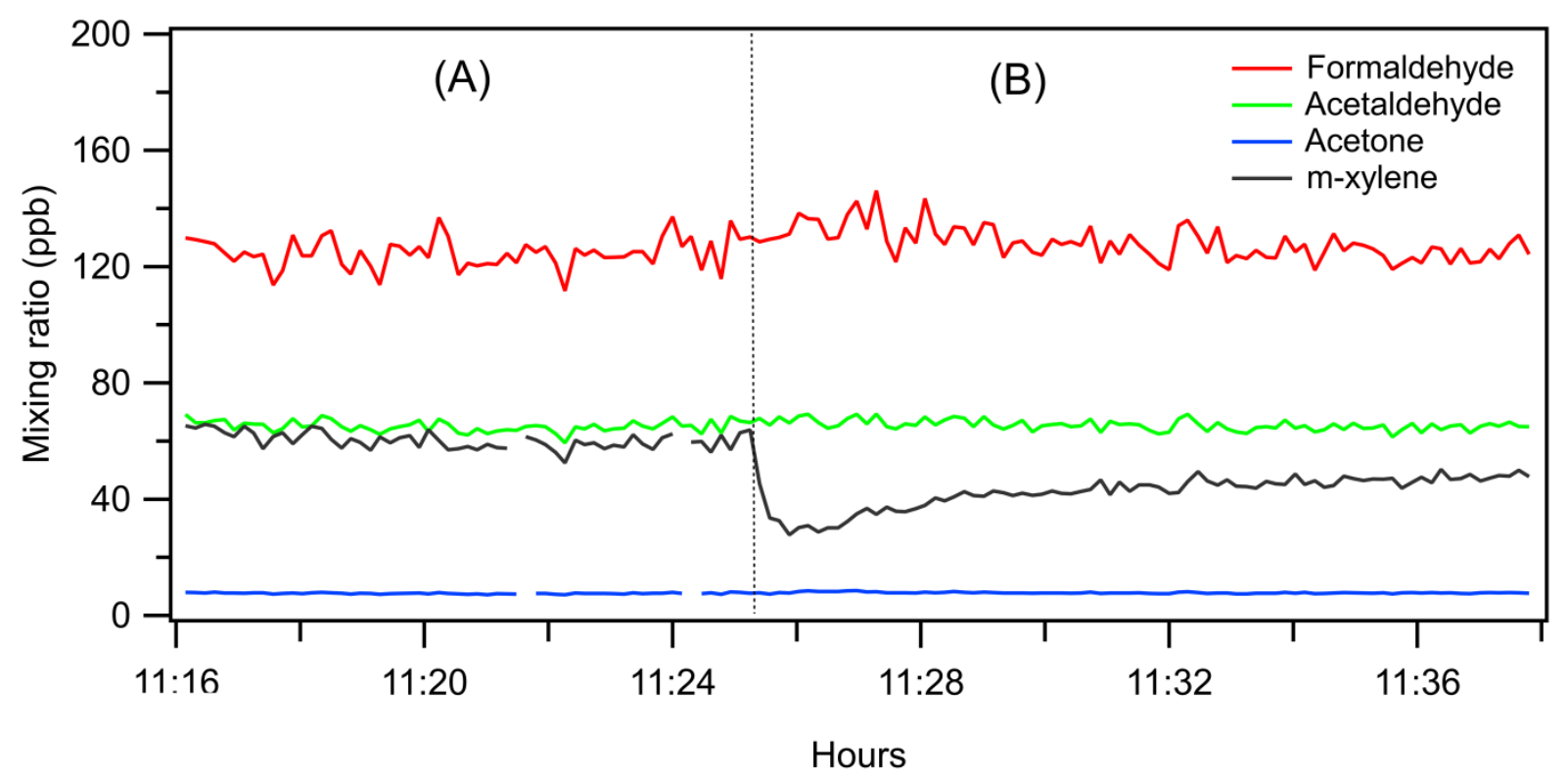

2 Figure 8: Temporal profile of formaldehyde (red line), acetaldehyde (green line), acetone 3 (blue line) and $m$-xylene (dark line) mixing ratio (ppb) at temperature: $296 \mathrm{~K}, \mathrm{RH}$ : $37 \%$, light 4 intensity: $18.6 \mathrm{~W} \mathrm{~m}^{-2}$, aging: 0 hour, photocatalytic paint: $7 \%$ of nano $\mathrm{TIO}_{2} \mathrm{PC} 500$. In the part 5 (A), injector is in position $\mathrm{P}_{0}$ and in part (B) in position $\mathrm{P}_{4}$.

In this experiment approx. $13 \mathrm{ppb}$ of $m$-xylene has been degraded in position $\mathrm{P}_{4}$. If $100 \%$ of this compound is converted, a $2.55 \cdot 10^{10}$ molecules $\mathrm{cm}^{-2} \mathrm{~s}^{-1}$ of VOCs would have been formed. In order to compare $m$-xylene consummation and by-products formation, we normalized observed mixing ratio to exposed paint surface area and reaction time to obtain the surface emission fluxes. For the mixing ratio and surface emission fluxes calculation, we used the method presented in detail by Morin et al. [23]. The surface emission fluxes of formaldehyde, acetaldehyde and acetone due to the reaction between molecules present in the binder and radical species produced by the photocatalyst $\left(\right.$ nano- $\left.\mathrm{TiO}_{2}\right)$ is $1.77 \cdot 10^{11}, 9.33 \cdot 10^{10}$, $1.07 \cdot 10^{10}$ molecules $\mathrm{cm}^{-2} \mathrm{~s}^{-1}$, respectively. The sum of surface emissions fluxes for these three compounds is $2.81 \cdot 10^{11}$ molecules $\mathrm{cm}^{-2} \mathrm{~s}^{-1}$. The additional emission of VOCs due to $m$-xylene degradation would correspond to an increase of about $9 \%$ of the surface emission flux. Moreover, a part of degraded $m$-xylene is mineralized to $\mathrm{CO}_{2}$ and $\mathrm{H}_{2} \mathrm{O}$ [43,44]. Debono et al. [43] observed a mineralization up to $76 \%$ for toluene that decreased the quantity of VOCs 
1 potentially formed at $2 \%$ or $5.81 \cdot 10^{9}$ molecules $\mathrm{cm}^{-2} \mathrm{~s}^{-1}$ which represents the uncertainly of

2 the measurements. For this reason, no difference has been observed in the mixing ratios of

3 this by-product between the position $\mathrm{P}_{0}$ and $\mathrm{P}_{4}$ (Figure 8); hence, the formed by-products

4 cannot be determined in this study.

5 To identify and quantify the formed products due to the degradation of $m$-xylene, the same

6 approach as Debono et al. [43] should be applied based on pure nano- $\mathrm{TiO}_{2}$. This method will

7 allow to determine the formed by-product but it will not be relevant from environmental point

8 of view. Surely, many efforts are needed to optimize the photocatalytic paints and establish as

9 a safe option for removal of indoor pollutants.

\section{CONCLUSION}

The influence of nano- $\mathrm{TiO}_{2}$ content, relative humidity, light intensity, surface temperature, pigment volume concentration, type of nanoparticles and aging, on the degradation of $m$ xylene on photocatalytic paints have been assessed under UV irradiation. The obtained results contribute to improve the knowledge on a poorly documented area that is the removal of VOCs by photocatalytic paints in indoor air. The results are crucial for the development of an optimal formula for photocatalytic paint as a function of environmental and physical parameters.

The increase of nano- $\mathrm{TiO}_{2}$ content and the PVC improve the removal of $m$-xylene by a factor of 3. The application of innovative CNC nanoparticles do not impact significantly the photocatalytic activity of the paint in comparison of widely used $\mathrm{TiO}_{2}$ nanoparticles. Paint aging has no influence on removal of $m$-xylene by paint containing CNC photocatalyst but the removal efficiency increased for the paints containing $\mathrm{PC} 500$ nano- $\mathrm{TiO}_{2}$. However, the aging of the paint implies environmental problem because of the emission of nanoparticles in the 
air. This subject is out of the scope in this study but deserves an attention from a healthcare point of view.

The increase of light intensity improved the removal efficiency of $m$-xylene by a factor 5 . In contrast, high surface temperature and RH slowed down the degradation of $m$-xylene.

In order to assess the impact of photocatalytic paints on indoor air quality, we suggest a simple calculation to compare the lifetime of $m$-xylene through the major removal pathways in an indoor environment [45]. The consumption of $m$-xylene by photocatalytic paint is considered for a model room of $50 \mathrm{~m}^{3}$ with a constant irradiated wall surface of $3 \mathrm{~m}^{2}$. From the experimental results from this study, the removal rate of $m$-xylene is estimated to be $7.3 \cdot 10^{-6} \mathrm{~s}^{-1}$ for a non-aged photocatalytic paint containing $7 \%$ of nano- $\mathrm{TiO}_{2}$ with a $\mathrm{PVC}$ of $72 \%$ at $40 \%$ of $\mathrm{RH}$ under a spectral irradiation intensity of $8.8 \mathrm{~W} \mathrm{~m}^{-2}$ and a surface temperature of $298 \mathrm{~K}$. The lifetime associated to this removal pathway is approximatively 38 hours while the lifetime due to the oxidation by gas-phase $\mathrm{OH}$ radicals (assuming a mean $\mathrm{OH}$ concentration of $5 \cdot 10^{5}$ radicals $\mathrm{cm}^{-3}$ [46] and bimolecular rate constant of $\mathrm{k}_{\mathrm{OH}+m \text { - }}$ xylene $=2.3 \cdot 10^{-11}$ molecules $\mathrm{cm}^{-3} \mathrm{~s}^{-1}$ [47]) is 24 hours, and 2 hours for a typical air exchange rate of $0.5 \mathrm{~h}^{-1}$ [48]. Under these conditions, the main removal pathway of $m$-xylene is air exchange rate which account for more than $99 \%$ of its elimination. The photocatalytic degradation and $\mathrm{OH}$ oxidation account only minor contribution to the removal of $m$-xylene from the indoor air.

The future formulation of an optimized photocatalytic paint should consider the influence of the physical (quantity of $\mathrm{TiO}_{2}$ nanoparticles, type of photocatalyst, and PVC), and environmental (RH, light intensity, surface temperature) parameters on the degradation of indoor air pollutants. In the future, photocatalytic oxidation must be studied under visible irradiation because $45 \%$ of solar irradiation is in visible region $(400-700 \mathrm{~nm})$ against only $4 \%$ for in the UV region of wavelengths. 


\section{ACKNOWLEDGMENTS}

2 The authors acknowledge gratefully LABEX SERENADE (no.ANR-11-LABX-0064) funded

3 by the French National Research Agency (ANR) through the PIA (Programme Investissement

4 d'Avenir). S.G. acknowledges the funding support by National Natural Science Foundation of

5 China (No. 41773131, No. 41977187).

\section{ASSOCIATED CONTENT}

\section{Supporting Information}

8 Typical experiment of $m$-xylene degradation (Figure S1), loss of gas phase $m$-xylene as a 9 function of exposure time (Figure S2).

\section{Notes}

The authors declare no competing financial interest.

\section{REFERENCES}

(1) Bolden, A. L.; Kwiatkowski, C. F.; Colborn, T. New Look at BTEX: Are Ambient Levels a Problem? Environ. Sci. Technol. 2015, 49 (9), 5261-5276. https://doi.org/10.1021/es505316f.

(2) Salthammer, T.; Mentese, S.; Marutzky, R. Formaldehyde in the Indoor Environment. Chem. Rev. 2010, 110 (4), 2536-2572. https://doi.org/10.1021/cr800399g.

(3) Thepanondh, S.; Varoonphan, J.; Sarutichart, P.; Makkasap, T. Airborne Volatile Organic Compounds and Their Potential Health Impact on the Vicinity of Petrochemical Industrial Complex. Water, Air, Soil Pollut. 2011, 214 (1), 83-92. https://doi.org/10.1007/s11270-010-0406-0.

(4) Verriele, M.; Schoemaecker, C.; Hanoune, B.; Leclerc, N.; Germain, S.; Gaudion, V.; 
Locoge, N. The MERMAID Study: Indoor and Outdoor Average Pollutant Concentrations in 10 Low-Energy School Buildings in France. Indoor Air 2015, 26 (5), 702-713. https://doi.org/10.1111/ina.12258.

(5) Geiss, O.; Giannopoulos, G.; Tirendi, S.; Barrero-Moreno, J.; Larsen, B. R.; Kotzias, D. The AIRMEX Study - VOC Measurements in Public Buildings and Schools/Kindergartens in Eleven European Cities: Statistical Analysis of the Data. Atmos. Environ. 2011, 45 (22), 3676-3684. https://doi.org/https://doi.org/10.1016/j.atmosenv.2011.04.037.

(6) Roberts, J., Nelson, W. . National Human Activity Pattern Survey Data Base. United States Environ. Prot. Agency 1995.

(7) Sattler, M. L.; Liljestrand, H. M. Method for Predicting Photocatalytic Oxidation Rates of Organic Compounds. J. Air Waste Manage. Assoc. 2003, 53 (1), 3-12. https://doi.org/10.1080/10473289.2003.10466119.

(8) Zhong, L.; Haghighat, F.; Blondeau, P.; Kozinski, J. Modeling and Physical Interpretation of Photocatalytic Oxidation Efficiency in Indoor Air Applications. Build. Environ. 2010, 45 (12), 2689-2697. https://doi.org/https://doi.org/10.1016/j.buildenv.2010.05.029.

(9) Zhong, L.; Haghighat, F. Photocatalytic Air Cleaners and Materials Technologies Abilities and Limitations. Build. Environ. 2015, 91, 191-203. https://doi.org/https://doi.org/10.1016/j.buildenv.2015.01.033.

(10) Zhao, J.; Yang, X. Photocatalytic Oxidation for Indoor Air Purification: A Literature Review. Build. Environ. 2003, 38 (5), 645-654. https://doi.org/https://doi.org/10.1016/S0360-1323(02)00212-3. 
1 (11) INRS. Benzène, Fiche Toxicologique Nº49; 2009.

2

3

(12) INRS. Toluène, Fiche Toxicologique N74; 2012.

(13) INRS. Ethylbenzène, Fiche Toxicologique $N^{\circ} 266 ; 2018$.

(14) INRS. Xylènes, Fiche Toxicologique N77; 2009.

(15) Hazrati, S.; Rostami, R.; Farjaminezhad, M.; Fazlzadeh, M. Preliminary Assessment of BTEX Concentrations in Indoor Air of Residential Buildings and Atmospheric Ambient Air in Ardabil, Iran. Atmos. Environ. 2016, 132, 91-97. https://doi.org/https://doi.org/10.1016/j.atmosenv.2016.02.042.

(16) INERIS. Exposition Par Inhalation Au Benzène, Toluène, Éthylbenzène, et Xylènes (BTEX) Dans l'air; 2004.

(17) Palau, J.; Penya-Roja, J. M.; Gabaldón, C.; Javier Álvarez-Hornos, F.; Sempere, F.; Martínez-Soria, V. UV Photocatalytic Oxidation of Paint Solvent Compounds in Air Using an Annular TiO2-Supported Reactor. J. Chem. Technol. Biotechnol. 2011, 86 (2), 273-281. https://doi.org/10.1002/jctb.2515.

(18) Martinez, T.; Bertron, A.; Escadeillas, G.; Ringot, E.; Simon, V. BTEX Abatement by Photocatalytic TiO2-Bearing Coatings Applied to Cement Mortars. Build. Environ. 2014, 71, 186-192. https://doi.org/https://doi.org/10.1016/j.buildenv.2013.10.004.

(19) Jo, W.-K.; Park, K.-H. Heterogeneous Photocatalysis of Aromatic and Chlorinated Volatile Organic Compounds (VOCs) for Non-Occupational Indoor Air Application. Chemosphere 2004, 57 (7), 555-565. https://doi.org/https://doi.org/10.1016/j.chemosphere.2004.08.018.

(20) Ao, C. H.; Lee, S. C.; Mak, C. L.; Chan, L. Y. Photodegradation of Volatile Organic Compounds (VOCs) and NO for Indoor Air Purification Using TiO2: Promotion versus 
Inhibition Effect of NO. Appl. Catal. B Environ. 2003, 42 (2), 119-129.

https://doi.org/https://doi.org/10.1016/S0926-3373(02)00219-9.

(21) Strini, A.; Cassese, S.; Schiavi, L. Measurement of Benzene, Toluene, Ethylbenzene and o-Xylene Gas Phase Photodegradation by Titanium Dioxide Dispersed in Cementitious Materials Using a Mixed Flow Reactor. Appl. Catal. B Environ. 2005, 61 (1-2), 90-97. https://doi.org/10.1016/J.APCATB.2005.04.009.

(22) Tryba, B.; Homa, P.; Wróbel, R. J.; Morawski, A. W. Photocatalytic Decomposition of Benzo-[a]-Pyrene on the Surface of Acrylic, Latex and Mineral Paints. Influence of Paint Composition. J. Photochem. Photobiol. A Chem. 2014, 286, 10-15. https://doi.org/https://doi.org/10.1016/j.jphotochem.2014.04.012.

(23) Morin, J.; Gandolfo, A.; Temime-Roussel, B.; Strekowski, R.; Brochard, G.; Bergé, V.; Gligorovski, S.; Wortham, H. Application of a Mineral Binder to Reduce VOC Emissions from Indoor Photocatalytic Paints. Build. Environ. 2019, 156, 225-232. https://doi.org/10.1016/J.BUILDENV.2019.04.031.

(24) Gandolfo, A.; Marque, S.; Temime-Roussel, B.; Gemayel, R.; Wortham, H.; TruffierBoutry, D.; Bartolomei, V.; Gligorovski, S. Unexpectedly High Levels of Organic Compounds Released by Indoor Photocatalytic Paints. Environ. Sci. Technol. 2018, 52 (19), 11328-11337. https://doi.org/10.1021/acs.est.8b03865.

(25) Bartolomei, V.; Sörgel, M.; Gligorovski, S.; Alvarez, E. G.; Gandolfo, A.; Strekowski, R.; Quivet, E.; Held, A.; Zetzsch, C.; Wortham, H. Formation of Indoor Nitrous Acid (HONO) by Light-Induced NO2 Heterogeneous Reactions with White Wall Paint. Environ. Sci. Pollut. Res. 2014, 21 (15), 9259-9269. https://doi.org/10.1007/s11356014-2836-5.

(26) Gandolfo, A.; Bartolomei, V.; Truffier-Boutry, D.; Temime-Roussel, B.; Brochard, G.; 
Bergé, V.; Wortham, H.; Gligorovski, S. The Impact of Photocatalytic Paint's Porosity on Indoor NOx and HONO Levels. Phys. Chem. Chem. Phys. 2019. https://doi.org/10.1039/C9CP05477D.

(27) ISO. 16474-3:2013, Paints and Varnishes- Methods of Exposureto Laboratory Light Sources-Part 3:Fluorescent UV Lamps. 2013.

(28) Truffier-Boutry, D.; Fiorentino, B.; Bartolomei, V.; Soulas, R.; Sicardy, O.; Benayad, A.; Damlencourt, J.-F.; Pepin-Donat, B.; Lombard, C.; Gandolfo, A.; Wortham, H.; Brochard, G.; Audemard, A.; Porcar, L.; Gebel, G.; Gligorovski, S. Characterization of Photocatalytic Paints: A Relationship between the Photocatalytic Properties - Release of Nanoparticles and Volatile Organic Compounds. Environ. Sci. Nano 2017, 4 (10), 1998-2009. https://doi.org/10.1039/C7EN00467B.

(29) Gandolfo, A.; Bartolomei, V.; Gomez Alvarez, E.; Tlili, S.; Gligorovski, S.;

Kleffmann, J.; Wortham, H. The Effectiveness of Indoor Photocatalytic Paints on NOx and HONO Levels. Appl. Catal. B Environ. 2015, 166-167, 84-90. https://doi.org/https://doi.org/10.1016/j.apcatb.2014.11.011.

(30) Finlayson-Pitts, B. J.; Pitts, J. N. Chemistry of the Upper and Lower Atmosphere: Theory, Experiments, and Applications; Academic Press, 2000.

(31) George, C.; Strekowski, R. S.; Kleffmann, J.; Stemmler, K.; Ammann, M. Photoenhanced Uptake of Gaseous NO2 on Solid Organic Compounds: A Photochemical Source of HONO? Faraday Discuss. 2005, 130 (0), 195-210. https://doi.org/10.1039/B417888M.

(32) El Zein, A.; Bedjanian, Y. Interaction of $\mathrm{NO}_{2}$ with $\mathrm{TiO}_{2}$ Surface under UV Irradiation: Measurements of the Uptake Coefficient. Atmos. Chem. Phys. 2012, 12 (2), 10131020. https://doi.org/10.5194/acp-12-1013-2012. 
1 (33) Behnke, W.; George, C.; Scheer, V.; Zetzsch, C. Production and Decay of CINO2 from the Reaction of Gaseous $\mathrm{N} 2 \mathrm{O} 5$ with $\mathrm{NaCl}$ Solution: Bulk and Aerosol Experiments. $J$. Geophys. Res. Atmos. 1997, 102 (D3), 3795-3804. https://doi.org/10.1029/96JD03057.

(34) Cooney, D. O.; Kim, S.-S.; James Davis, E. Analyses of Mass Transfer in Hemodialyzers for Laminar Blood Flow and Homogeneous Dialysate. Chem. Eng. Sci. 1974, 29 (8), 1731-1738. https://doi.org/https://doi.org/10.1016/0009-2509(74)870314.

(35) Hoffmann, M. R.; Martin, S. T.; Choi, W.; Bahnemann, D. W. Environmental Applications of Semiconductor Photocatalysis. Chem. Rev. 1995, 95 (1), 69-96. https://doi.org/10.1021/cr00033a004.

(36) Toor, A. P.; Verma, A.; Jotshi, C. K.; Bajpai, P. K.; Singh, V. Photocatalytic Degradation of Direct Yellow 12 Dye Using UV/TiO2 in a Shallow Pond Slurry Reactor. Dye. Pigment. 2006, 68 (1), 53-60. https://doi.org/https://doi.org/10.1016/j.dyepig.2004.12.009.

(37) Barakat, N. A. M.; Kanjwal, M. A.; Chronakis, I. S.; Kim, H. Y. Influence of Temperature on the Photodegradation Process Using Ag-Doped TiO2 Nanostructures: Negative Impact with the Nanofibers. J. Mol. Catal. A Chem. 2013, 366, 333-340. https://doi.org/https://doi.org/10.1016/j.molcata.2012.10.012.

(38) Giosuè, C.; Belli, A.; Mobili, A.; Citterio, B.; Biavasco, F.; Ruello, M.; Tittarelli, F. Improving the Impact of Commercial Paint on Indoor Air Quality by Using Highly Porous Fillers. Buildings 2017, 7 (4), 110. https://doi.org/10.3390/buildings7040110.

(39) Jansson, I.; Suárez, S.; Garcia-Garcia, F. J.; Sánchez, B. Zeolite-TiO2 Hybrid Composites for Pollutant Degradation in Gas Phase. Appl. Catal. B Environ. 2015, 178, 100-107. https://doi.org/https://doi.org/10.1016/j.apcatb.2014.10.022. 
(40) Auvinen, J.; Wirtanen, L. The Influence of Photocatalytic Interior Paints on Indoor Air Quality. Atmos. Environ. 2008, 42 (18), 4101-4112. https://doi.org/https://doi.org/10.1016/j.atmosenv.2008.01.031.

(41) Hodgson, A. T.; Destaillats, H.; Sullivan, D. P.; Fisk, W. J. Performance of Ultraviolet Photocatalytic Oxidation for Indoor Air Cleaning Applications. Indoor Air 2007, 17 (4), 305-316. https://doi.org/10.1111/j.1600-0668.2007.00479.x.

(42) Farhanian, D.; Haghighat, F. Photocatalytic Oxidation Air Cleaner: Identification and Quantification of by-Products. Build. Environ. 2014, 72, 34-43. https://doi.org/10.1016/J.BUILDENV.2013.10.014.

(43) Debono, O.; Hequet, V.; Le Coq, L.; Locoge, N.; Thevenet, F. VOC Ternary Mixture Effect on Ppb Level Photocatalytic Oxidation: Removal Kinetic, Reaction Intermediates and Mineralization. Appl. Catal. B Environ. 2017, 218, 359-369. https://doi.org/10.1016/J.APCATB.2017.06.070.

(44) Binas, V.; Stefanopoulos, V.; Kiriakidis, G.; Papagiannakopoulos, P. Photocatalytic Oxidation of Gaseous Benzene, Toluene and Xylene under UV and Visible Irradiation over Mn-Doped TiO2 Nanoparticles. J. Mater. 2019, 5 (1), 56-65. https://doi.org/10.1016/J.JMAT.2018.12.003.

(45) Manoukian, A.; Quivet, E.; Temime-Roussel, B.; Nicolas, M.; Maupetit, F.; Wortham, H. Emission Characteristics of Air Pollutants from Incense and Candle Burning in Indoor Atmospheres. Environ. Sci. Pollut. Res. 2013, 20 (7), 4659-4670. https://doi.org/10.1007/s11356-012-1394-y.

(46) Carslaw, N. A New Detailed Chemical Model for Indoor Air Pollution. Atmos. Environ. 2007, 41 (6), 1164-1179. https://doi.org/https://doi.org/10.1016/j.atmosenv.2006.09.038. 
1 (47) Kramp, F.; Paulson, S. E. On the Uncertainties in the Rate Coefficients for OH Reactions with Hydrocarbons, and the Rate Coefficients of the 1,3,5-Trimethylbenzene and m-Xylene Reactions with OH Radicals in the Gas Phase. J. Phys. Chem. A 1998, 102 (16), 2685-2690. https://doi.org/10.1021/jp973289o.

(48) Murray, D. M.; Burmaster, D. E. Residential Air Exchange Rates in the United States: Empirical and Estimated Parametric Distributions by Season and Climatic Region. Risk Anal. 1995, 15 (4), 459-465. https://doi.org/10.1111/j.1539-6924.1995.tb00338.x. 